\title{
TOLERANCE AS AN EXHIBITION OF HUMANISM FOR THE RISING GENERATION
}

\author{
Marina Marchenoka \\ Rezekne Academy of Technologies, Latvia
}

\begin{abstract}
The mankind is going the way of the fast scientific and technological progress, at the same time feeling shortage of respect, kindness, and mutual understanding in this global process. The modern scientific and technical progress is leaving behind the moral or ethical progress stimulating emergence of new forms of spiritual impoverishment, cruelty, violence and hostility. The best humanistic principles, which are based on mutual aid, sympathy are depreciating, blurring the very concept of the moral. The situation gives evidence of the process of dehumanisation of the society, when the person's value becomes lower than other values.

The relevance of examination of tolerance in the aspect of humanisation is determined by the society's demand for development of relations of a new type, which would be grounded on humanistic base, where every person is regarded as the highest value, where there is a priority of general human values against ethnic values, where the basic principle of people's relations are: benevolence, humanity, mercy and respect.
\end{abstract}

Keywords: humanism, humanisation, tolerance/intolerance, teenagers', modern society.

\section{Introduction}

Global migration of the population in Europe and socially economical sequences of this process are one of the most topical phenomena of the contemporary world. Europe is going the way of extension of interrelations and interdependence of different countries and peoples transforming monocultural countries into polyethnic communities.

Changes in moral values, rejection of a different opinion or viewpoint demonstrate expression of intolerance, and its result can reveal itself in a wide range: from simple impoliteness, disdainful attitude to other people and anger up to ethnic clean-up and genocide.

The relevance of examination of tolerance in the aspect of humanisation is determined by the society's demand for development of relations of a new type, which would be grounded on humanistic base, where every person is regarded as the highest value, where there is a priority of general human values against ethnic values, where the basic principle of people's relations are: benevolence, humanity, mercy and respect. 
The Aims of the research is: examine the problem of tolerance theoretically in the aspect of humanisation of the modern society and to discover their interconnection.

The Methods of the research are: scientifically theoretical analysis of the problem: philosophical conceptions of humanism (Confucius; M. Cicero; I.Kant; M. Gulen; A. Schopenhauer), humanistic paradigm (Z. Chehlova), psychological analysis, affecting various aspects of tolerance as a complicated socially psychological phenomenon (Declaration of Principles on Tolerance, UNESCO; G. W. Allport; G. Soldatova), the empirical research the level of tolerance of teenagers in Latvia (M. Marchenoka).

\section{Humanism as a moral category}

"Live with other people so that you friends would not become your adversaries, but your adversaries would become your friends" (Pythagoras, 570 490 BC). The famous ancient Greek philosopher's words are also topical in the modern society, when the mankind is going the way of the fast scientific and technological progress, at the same time feeling shortage of respect, kindness, and mutual understanding in this global process. The modern scientific and technical progress is leaving behind the moral or ethical progress stimulating emergence of new forms of spiritual impoverishment, cruelty, violence and hostility. The best humanistic principles, which are based on mutual aid, sympathy are depreciating, blurring the very concept of the moral. The situation gives evidence of the process of dehumanisation of the society, when the person's value becomes lower than other values.

The word "humanism" is derived from the Latin concept humanitas, meaning "humanity", humanus - "humane", homo -"human being", meaning worldview, based on the principles of equality, justice, humanity of people's relations, enriched with love to people, respect to human dignity, care about people's welfare (Философский энциклопедический словарь, 2009).

Humanism as a historical property of the mankind is impossible without humanity, which appeared as a need in opposition to the evil, as a regulator of people's relations, and contains all norms and rules of person's behaviour in the society, which has been forming during many centuries (Васильев, 2011).

In order to answer the question "What kind of a person must you be to be a human being?", the Chinese philosopher and thinker Confucius (551-479 BC) developed humanistic theses, grounded on ancient moral traditions, emphasizing such important ethic rules as respect to parents and ancestors, history and traditions of the country. There is a legend saying that when Confucius was asked by his apprentices "Is it possible to use one word for definition of people's moral actions, that is to say how to behave in different life situations to be a person of 
worth of ancestors", Confucius replied: "There is the word 'ren', meaning the ideal principle of people's relations: benevolence, humanity, kind-heartedness and respect" (Васильев, 2006).

In the $1^{\text {st }}$ century BC the concept "humanism" was used by the famous Roman philosopher and orator Marcus Tullio Cicero (106-43 BC), who envisaged it together with such value personal characteristics as piety (pietas), worship of gods (religio), constancy (constantia), honesty (fides) and understanding other people (intellectus) (Cicero, 2000: 91).

During the Renaissance (XIV - XVII) "humanism" was regarded as "a set of opinions and ideas on the basis of respect to a person, developing characteristics of morality in people, and on the basis of such spiritual values as philosophy, literature, art (T. More, T. Campanella, F. Rabelais, etc.).

The moral basis of humanism was also elaborated by English philosophers (F. Bacon, T. Hobbes, J. Locke), French writers and philosophers (D. Diderot, J.J. Rousseau), German philosophers (G. Leibniz, I. Kant, L. Feuerbach) and others. Their main thesis is that "during the time of crisis of the society the world of people's interrelations collapses, which is accompanied by demolition of peoples' traditional morals and spiritual foundations" (Васильев, 2011).

The principal philosophical issue of Immanuel Kant $(1724$ - 1804) was the human being and his behaviour. In his work "Conjectural Beginning of Human History" I. Kant made the conclusion that civilisation gave the man the opportunity to become the man. "The man becomes the man, when he overcomes his animal nature, establishes the rules of people's life and behaviour. Civilisation taught people to respect other people, to take into account other people's interests, needs and rights" (Kant, 1993). The philosopher believes that despite multiple deviations in people's behaviour in the historical past and in the present, the tendency of strengthening and development of humanity must be the main tendency in the history. In this regard I. Kant distinguishes two basic components of humanity in the society: "firstly, the man makes himself the man, respecting the man in himself, and secondly the man makes himself the man respecting the man in the other person. Nothing good is possible without a good will, and it is not important what talents, possibilities and virtues a person possesses. Good will is the basic personal feature and it is irreplaceable for a moral action" (Kant, 1993). These ideas are one of the deepest and most significant in humanist Kant's philosophy.

Turkish writer, philosopher and thinker M. Fethullah Gulen (1941), carrying on I. Kant's ideas, affirmed that "any person - a man or a woman, a youngster or an old man, white or black - is a respected, protected and untouchable creature. Their honour and dignity must not be desecrated, no one can exclude them from their native land, and their independence cannot be ruined. Furthermore, it is forbidden for them to commit such crimes against others. In truth, love is a rose 
in our beliefs, the peace of the heart, which will never wither. This love transforms into the basic humanism, and in its framework people grow love to other people in themselves and to the entire creation and show this love to those, who support the world and render services to it" (Gulen, 2004).

When systemising various concepts of the word 'humanism', it is possible to distinguish three main groups of its meaning. Humanism is:

1. Progressive study of the époque of Renaissance (free development of the person on the basis of such spiritual values as philosophy, literature, art);

2. World outlook with its basic principles (equality, freedom, creative life, happiness without regard to national, religious, age-related, social and other specific features);

3. Attitude to people, expressed in respect, benevolence and sympathy.

The analysis of the content of the concept 'humanism' gives the possibility to define the content of the concept 'humanisation'. As a derivation of the word 'humanism' the given concept is the social value-related and morally psychological basis of the society and people's relations.

\section{Tolerance as the basis for humanisation of the society}

Research and the daily routine show that one of the specific features of the modern society is the fast growth of aggressiveness, rejection of other people's different opinion, judgement and needs. Development of the modern humane society is impossible without development and increase of the level of the modern man's tolerance, because "humanisation is harmonisation of the man's personality' relations with his essence and people around him" (Chehlova, 2014).

Urgency of development of tolerance is grounded in the fact that ,mutual understanding" stands out as a social and personal value, since it gives the possibility to ensure interaction between people for the development of the society. Absence of mutual understanding leads to destruction of the integrity of social interrelations, and as a sequence - to self-destruction of the personality, to aggression. Presence of interaction, based on mutual understanding, on the contrary, contributes to development of the individual's feeling of safety, confidence in his actions and as a sequence - to development of the person's values.

The problem of tolerance is rather new in research both in Latvia and abroad. First studies on this topic appeared only in the middle 90s (Gordon Willard Allport, Borba Michele, Kamungeremu David, Vogt W. Paul, Wandberg Robert). The important factor of the world acceptance of the necessity to study the given problem became the Declaration of Principles on Tolerance approved by Resolution 5.61 of UNESCO General Conference on November 16, 1995. The 
Declaration provides the international definition of the meaning of tolerance and the opposite concept, i.e. intolerance. As appears from the above, ,tolerance is respect, acceptance and appreciation of the rich diversity of our world's cultures, our forms of expression and ways of being human. Tolerance, the virtue that makes peace possible, contributes to the replacement of the culture of war by a culture of peace. Consistent with respect for human rights, the practice of tolerance does not mean toleration of social injustice or the abandonment or weakening of one's convictions. It means that one is free to adhere to one's own convictions and accepts that others adhere to theirs. It means accepting the fact that human beings, naturally diverse in their appearance, situation, speech, behaviour and values, have the right to live in peace and to be as they are. It also means that one's views are not to be imposed on others. Intolerance is rejection of other people, unavailability to co-exist with other (different) people; it is expressed with destructive, conflict and aggressive behaviour" (Declaration of Principles on Tolerance, UNESCO, 1995).

In connection with the described above it is necessary to concretize features of tolerant and intolerant personalities. One of the first scientists who offered general characteristics of tolerant and intolerant personalities was a representative of humanistic psychology Gordon Willard Allport. In his work ,The Nature of Prejudice" (1954), he laid methodological foundation of studying tolerance as a psychological phenomenon, separating out the following parameters of tolerant and intolerant personalities: (see Table 1).

Table 1 Parameters of tolerant and intolerant personalities (Allport, 1979)

\begin{tabular}{|c|c|c|}
\hline Parameters & Tolerant personality & Intolerant personality \\
\hline Self-orientation & $\begin{array}{l}\text { More self-oriented in work, } \\
\text { creative process, theoretical } \\
\text { reflection. In problematic } \\
\text { situations this person usually } \\
\text { blames himself/herself, but not the } \\
\text { surrounding people. Such people } \\
\text { seek after personal independence } \\
\text { more that after belonging to } \\
\text { external institutes and authorities, } \\
\text { because they do not need anyone } \\
\text { to hide behind. }\end{array}$ & $\begin{array}{l}\text { In problematic situations, this } \\
\text { person blames other people more } \\
\text { that himself/herself. He/she seeks } \\
\text { after belonging to external } \\
\text { institutes and authorities. }\end{array}$ \\
\hline Responsibility & $\begin{array}{l}\text { Does not abdicate all } \\
\text { responsibility, is ready to be } \\
\text { responsible for his/her actions. }\end{array}$ & $\begin{array}{l}\text { Believes that events happening } \\
\text { around do not depend on him/her. } \\
\text { Tries to disclaim responsibility for } \\
\text { everything that is going on around. } \\
\text { This peculiarity leads to } \\
\text { development of prejudice to other } \\
\text { people. The position is following: }\end{array}$ \\
\hline
\end{tabular}




\begin{tabular}{|c|c|c|}
\hline & & $\begin{array}{l}\text { I don't hate people and I don't } \\
\text { harm other people, but they hate } \\
\text { and hurt me. }\end{array}$ \\
\hline $\begin{array}{c}\text { Need in } \\
\text { distinctness }\end{array}$ & Sees the world in its variety. & $\begin{array}{l}\text { Divides the world into two parts: } \\
\text { black and white. There are only } \\
\text { two kinds of people: bad and good. } \\
\text { Emphasises differences between } \\
\text { „our" and ,alien", has a difficulty } \\
\text { to accept event neutrally. This } \\
\text { person accepts or does not accept } \\
\text { them. }\end{array}$ \\
\hline Empathy ability & $\begin{array}{l}\text { The ability is defined as a social } \\
\text { sensitivity, ability to formulate } \\
\text { more adequate judgements about } \\
\text { other people, i.e. these people } \\
\text { assess adequately both tolerant and } \\
\text { intolerant people. }\end{array}$ & $\begin{array}{l}\text { Assesses his/her partners in his/her } \\
\text { own image. }\end{array}$ \\
\hline $\begin{array}{l}\text { Knowledge about } \\
\text { oneself }\end{array}$ & $\begin{array}{l}\text { Tries to understand his/her merits } \\
\text { and demerits. Has a critical } \\
\text { attitude to himself/herself and } \\
\text { restrains from blaming other } \\
\text { people in all his/her troubles. }\end{array}$ & $\begin{array}{l}\text { Sees more merits in } \\
\text { himself/herself than demerits. Is } \\
\text { disposed to blame other people in } \\
\text { his/her troubles. }\end{array}$ \\
\hline Immunity & $\begin{array}{l}\text { Usually feels safe, and therefore } \\
\text { does not need to protect from other } \\
\text { people. Absence of threat and } \\
\text { confidence that it is possible to } \\
\text { cope with it is an important } \\
\text { precondition on upbringing the } \\
\text { tolerant person. }\end{array}$ & $\begin{array}{l}\text { Has difficulties in living both with } \\
\text { other and with himself/herself. Is } \\
\text { afraid of the social environment } \\
\text { and of himself/herself: is afraid of } \\
\text { instincts, feelings, lives with a } \\
\text { constant feeling of threat. }\end{array}$ \\
\hline $\begin{array}{l}\text { Freedom and } \\
\text { democracy } \\
\text { preference }\end{array}$ & $\begin{array}{l}\text { Does not pay attention to hierarchy } \\
\text { in the society, prefers living in a } \\
\text { free, democratic society. }\end{array}$ & $\begin{array}{l}\text { For this person the social hierarchy } \\
\text { is extremely important, regulates } \\
\text { his/her life in the authoritarian } \\
\text { society with strong power. This } \\
\text { person believes that strong } \\
\text { discipline is very important. }\end{array}$ \\
\hline Sense of humour & $\begin{array}{l}\text { Has a sense of humour and is able } \\
\text { to laugh at himself/herself, his/her } \\
\text { demerits and does not strive for } \\
\text { dominancy amongst the others. }\end{array}$ & $\begin{array}{l}\text { Does not have sense of humour } \\
\text { and is not able to laugh at his/her } \\
\text { demerits. }\end{array}$ \\
\hline
\end{tabular}

The optimal age for development of the tolerant cognition and tolerance settings is juvenile age, because it is the age of development of mental processes and formation of personality. It is the stage of development, which gives the best possibilities for purposeful formation of his/her physical, mental and sociocultural characteristics. This age boundary is characterised by the child's transition to another social conditions, when he/she starts living according to laws of the adult 
society, he/she is actively developing as a subject of social relations and starts bearing responsibility for his/her actions. In this period you can trace the polarity of mind: purposefulness, perseverance - impetuosity, instability; increased selfconfidence, refusal to compromise in judgements - vulnerability and uncertainty in oneself; need in communication - wish to seclude oneself; aggressive behaviour - timidity; romantic appeal - cynicism, prudence; tenderness - cruelty. This age is ready for development of the life platform of motives and values, own views, beliefs, ability to react adequately on remarks, true and incorrect criticism, the ability to stand up for own opinion without disgracing other people.

On the basis of the empirical research aiming at discovering the level of tolerance amongst teenagers in Latvia (Marchenoka, 2014), the following conclusions were made: (see Table 2).

Table 2 The level of teenagers' tolerance in Latvia (Marchenoka, 2014)

\begin{tabular}{|c|c|c|}
\hline $\begin{array}{c}\text { Types } \\
\text { of the } \\
\text { tolerance }\end{array}$ & Block of affirmations & Result \\
\hline $\begin{array}{c}\text { Ethnic } \\
\text { tolerance }\end{array}$ & $\begin{array}{l}\text { Ethnic tolerance is the most striking } \\
\text { indicator of the level of society's } \\
\text { development, because in the process } \\
\text { of globalisation of the world and } \\
\text { culture confrontation, } \\
\text { "understanding" and "accept" of } \\
\text { another culture is the highest indicator } \\
\text { of its democracy and stability. } \\
\text { Statements that were included into } \\
\text { assessment: "It is correct to consider } \\
\text { that your people is better than other."; } \\
\text { "I want to have friends of various } \\
\text { nationalities.";"It is difficult to have } \\
\text { respectful attitude to some peoples."; } \\
\text { "Any religious currents have the right } \\
\text { to exist." As we can see, this unit } \\
\text { includes the ethnical prejudice, being } \\
\text { the most urgent in the modern society, } \\
\text { related to representatives of other } \\
\text { nationalities (according to the racial } \\
\text { characteristics). }\end{array}$ & $\begin{array}{l}\text { The results of the research showed } \\
\text { that the largest part of the interrogated } \\
\text { teenagers have the middle level of } \\
\text { ethnic tolerance }-70 \% \text {. Intolerance } \\
\text { was expressed by } 18.5 \% \text { of the } \\
\text { respondents. It is rather a high } \\
\text { indicator. It indicates that } \\
\text { representatives of this group, first, } \\
\text { will experience difficulties in } \\
\text { adapting in the society, and second, } \\
\text { they represent potential } \\
\text { "nationalists", which is not acceptable } \\
\text { within the framework of globalisation } \\
\text { of the world building the policy of } \\
\text { intercultural dialogue between } \\
\text { cultures and nations. } 11.5 \% \text { of } \\
\text { teenagers expressed the high level of } \\
\text { ethnic tolerance. This indicator can be } \\
\text { evaluated in two ways: on the one } \\
\text { hand, it is warrantable taking into } \\
\text { account the region of the } \\
\text { questionnaire, but on the other hand, } \\
\text { the accuracy of these data cannot be } \\
\text { evident in the context of the } \\
\text { respondents' internal knowledge of } \\
\text { "correct" answers, and it does not } \\
\text { mean that they share this opinion. But }\end{array}$ \\
\hline
\end{tabular}




\begin{tabular}{|c|c|c|}
\hline & & $\begin{array}{l}\text { even in this case, the result is also } \\
\text { positive, because the wish to be } \\
\text { tolerant is a step toward development } \\
\text { of a tolerant society. }\end{array}$ \\
\hline $\begin{array}{c}\text { Social } \\
\text { tolerance }\end{array}$ & $\begin{array}{l}\text { Social tolerance allowed of } \\
\text { examining expression of tolerance } \\
\text { and intolerance to various social } \\
\text { groups and to investigate individual's } \\
\text { attitude to some social processes. This } \\
\text { unit included the following } \\
\text { statements for assessment: "In mass } \\
\text { media any opinion may be } \\
\text { displayed."; "If the beggary and } \\
\text { vagabonds have problems, it's their } \\
\text { own fault."; "It is unpleasant to } \\
\text { communicate with untidy people."; } \\
\text { "All mentally diseased must be } \\
\text { isolated from the society."; "We can } \\
\text { help refugees not more than any other } \\
\text { people - local people have no less } \\
\text { problems."; "Newcomers must have } \\
\text { equal rights with the local people". }\end{array}$ & $\begin{array}{l}\text { The research showed the following } \\
\text { results. The high level of tolerance } \\
\text { was expressed by } 6 \% \text { of the } \\
\text { respondents, the middle level - } 75 \% \\
\text { and the low level }-19 \% \text {. The high } \\
\text { level is as } 6 \% \text { as lower than the high } \\
\text { level of ethnic tolerance discovered } \\
\text { within this research. It indicates that } \\
\text { the social situation in Latvia is more } \\
\text { critical than ethnic one in attitude to } \\
\text { various social groups. It is necessary } \\
\text { to comment that the juvenile age is } \\
\text { more categorical and aggressive. The } \\
\text { teenagers expressed particular } \\
\text { aversion to such social groups as } \\
\text { tramps and ill people. Almost } 100 \% \\
\text { of the respondents replied that they do } \\
\text { not want to communicate with untidy } \\
\text { people. The statement that } \\
\text { newcomers must have equal rights } \\
\text { with the local people also received } \\
\text { positive assessment. }\end{array}$ \\
\hline $\begin{array}{l}\text { Tolerance } \\
\text { as a } \\
\text { personality } \\
\text { trait }\end{array}$ & $\begin{array}{l}\text { Tolerance as a personality trait } \\
\text { diagnoses personal characteristics, } \\
\text { attitude and beliefs defining the } \\
\text { person's perception of the } \\
\text { surrounding world, mostly in relation } \\
\text { to other people from the point of view } \\
\text { of dissent and different behaviour. } \\
\text { This unit of evaluation of tolerance } \\
\text { included the following statements: "If } \\
\text { your friend betrayed you, you must } \\
\text { revenge."; "In a dispute there may be } \\
\text { only one correct point of view."; } \\
\text { "Even if I have a different opinion, } \\
\text { I'm ready to listen to other } \\
\text { viewpoints."; "If somebody is rude to } \\
\text { me, I'll pay him/her back."; "The } \\
\text { person having another opinion than } \\
\text { me, irritates me."; "Disorder irritates } \\
\text { me."; "I'd like to become more } \\
\text { tolerant to other people" }\end{array}$ & $\begin{array}{l}\text { The results of diagnosing of this } \\
\text { sector of tolerance are the highest if } \\
\text { we consider the indicator of the } \\
\text { higher level of tolerance, which } \\
\text { reached } 21 \% \text { and is the highest in } \\
\text { comparison with the previous blocks; } \\
\text { it indicates that tolerance to other } \\
\text { people in interpersonal aspect is more } \\
\text { developed in modern teenagers in } \\
\text { Latvia. The middle level reached } \\
66 \% \text {, and the low level was shown by } \\
13 \% \text { of the respondents. These } \\
\text { teenagers (13 \%) are so-called } \\
\text { "problematic" children, who usually } \\
\text { have bad relations with parents and } \\
\text { other teenagers due to the high level } \\
\text { of egoism and egocentrism. }\end{array}$ \\
\hline
\end{tabular}


„Values of tolerance - self-respect, justice, absence of violence, cooperation - obtain personal sense only when the schoolchild makes himself out, assesses his actions, their motives, when the moral self-control and the readiness for self-perfection of the personality are developed. Tolerance is always internal freedom, these are relations on equal terms, it is always the dialogical level of interaction" (Soldatova, 2003).

In A. Schopenhauer's philosophy the man's life is a constant fight between powers of egoism malevolence. Egoism is not able to accept counteractions against its aspirations. They provoke its "discontent, anger, hatred: it sees its enemy here who is to be eliminated" (Schopenhauer, 1992). The modern life creates challenges for people every day, causing new problems, and their solutions "require much wisdom: in order not to make a mistake you need tolerance, for understanding and accepting you need humanism" (Schopenhauer, 1992).

\section{Conclusion}

- The scientifically theoretical analysis of the concept 'humanism' gives the possibility to define it as a progressive study of the époque of Renaissance, as world outlook with its basic principles, as well as attitude to people expressed in respect, mercy and sympathy;

- On the basis of the analysis of the content of the concept "humanism" the content of the concept "humanisation" was also defined, which is regarded as a socially value-related and morally psychological basis of the society and relations between people;

- The concept "tolerance" is regarded as harmonisation of relations with other people, when any individual has the right to have his own opinion and respect the same right of other people;

- The concepts "humanism - humanisation" and "tolerance", which are examined in the article and are interrelated, and tolerance is sequence of humanisation. Both concepts are morally value-related basis of the society, where one of the values is the personality, man's dignity, respect, freedom of views and judgements, relations between people;

- The results of the research of ethnic tolerance showed that the largest part of the interrogated teenagers $(70 \%)$ has the middle level of tolerance, $11.5 \%$ expressed the high level of ethnic tolerance and intolerance was expressed by $18.5 \%$ of the interrogated teenagers. Despite the fact that the society in Latvia has always been multicultural society of and the research group was ethnically heterogeneous, the level of ethnic intolerance was rather high indicating that in case if the respondents do not change their standpoint in the future, they will have difficulties in adapting in the society and they can be considered as potential "nationalists", which is not acceptable in the 
process of globalisation of the world building the policy of intercultural dialogue between nations and cultures;

- Any society's future is in hands of the younger generation, which should strive for solidarity instead of dominance over others. Relations must be developed on the principles of tolerance and humanism. Understanding the nature of humanity and harmonisation of relations with other people is the basis for more efficient interaction with the society; its absence makes an individual's development impossible. Only in these conditions it is possible to overcome moral crisis and existing contradictions.

\section{References}

Allport, \& Gordon, W. (1979). The Nature of Prejudice, Addison Wesley. Reading, Mass.

Declaration of Principles on Tolerance, UNESCO. Retrieved from http://www.unesco.org/ webworld/peace_library/UNESCO/HRIGHTS/124-129.HTM

Gulen, M. F. (2004). Toward a Global Civilization of Love and Tolerance. New Jersey: The Light Inc., 8.

Kant, I. (1993). Grounding for the Metaphysics of Morals. Third edition. Trans. James W. Ellington. Indianapolis: Hackett Publishing Company.

Marchenoka, M. (2014). Tolerant personality as an objective need of the modern civil society. Education Reform in Comprehensive School: Education Content Research and Implementation Problems. The collection of scientific papers, Rezekne, 46 - 58.

Rainey, Lee Dian (2010). Confucius \& Confucianism: The essentials. Oxford: WileyBlackwell.

Schopenhauer, A. (1992). On the basis of morality, Freedom of faith and morals. Moscow, 196. Васильев, В. А. (2011). Нравственная основа гуманизма. Вестник МГЛУ, № 617.

Васильев, В. А. (2006). Конфуц̧ий о добродетели. Социально-гуманитарные знания, № 6, 132-146.

Конфуций (1995). Я верю в древность. Москва: Республика.

Солдатова, Г. (2002). Толерантность - норма жизни в мире разнообразия. Bonросы психологии. Москва: Наука.

Губский, Е. Ф. (2009). Философский энџиклопедический словарь. Москва: ИНФРА.

Цицерон, М. Т. (2000). Философские трактатыл. Москва: Наука.

Чехлов, М., Чехлова, 3., \& Рассолова, Т. (2014). Модель толерантного поведения как средство гуманизации педагогического процесса. Society, Integration. Education. Proceedings of the International Scientific Conference. Volume I, Rezekne, 372 - 380. 